\title{
Samuel Hahnemann's doctoral dissertation of 1779
}

S amuel Hahnemann (1755-1843), ${ }^{1}$ who was later to become the founder of homoeopathy, was born at Meißen, Saxonia, at a time when the physiologist Albrecht von Haller wrote about the irritability of muscles and nerves. Having graduated from the princely school of St Afra in 1775 he studied medicine in Leipzig until 1777 before he changed for Vienna because he found medicine in Germany too theoretically oriented and missed clinical experience. ${ }^{2}$ Only 9 months later he became a librarian and personal physician for doctor von Bruckenstadt, a baron at Hermannstadt in Transsylvania, founded as a Saxon colony in the 12th century, which is now Sibiu in Romania. Having served there-probably for financial reasons-until 1779, he went to Erlangen in Bavaria, whose university had been founded in 1743, and was registered there on 12 April 1779. One day earlier he had presented his doctoral dissertation called "Conspectus adfectuum spasmodicorum aetiologicus et therapeuticus", which he must have prepared beforehand. In it he dwells on the aetiological and therapeutic aspects of spasms by enumerating agents that were then said to induce or alleviate them.

On 20 printed pages he divides his thesis into 1) irritating agents; 2) divine or climatic influences; 3) emotion, sympathy, and antipathy; and 4) abundance or lack of powers and blood. He then elaborates on specific agents helpful with convulsions and seizures, agents acting on nerves, narcotics, expelling and cooling agents, relaxants, roborants, and corrigentia which "sweep up the tinder of spasms". Among the irritating agents he counts metals such as arsenic and mercury, but also belladonna and saffron, tobacco and hyoscyamus, many other herbal and animal poisons, bile and bad nutrition, coughing and meteorism, laxants and steam, worms and skull notches, crumbs, and pulmonary stones. Among the small number of climatic influences he mentions epidemic miasma, convulsive coughing, foul air in hospitals, and febrile eclampsia. The third chapter enumerates emotional affects, pain, cold feet, and childbirth. In the last chapter he illustrates abundance or lack of powers and blood by women's eclampsia during childbirth, masturbation, hiccup, agony, and trism. The remedies he recommends comprise a wealth of animal and herbal extracts, acids and salts, the bark of the china tree, but also tobacco and phlebotomy. ${ }^{3}$

The doctor's degree was granted to him on 10 August 1779, having passed all requirements including the doctoral viva (tentamen, examen rigorosum, and disputation). ${ }^{45}$ Regretfully the document testifying this academic procedure was lost to the effect that we do not know the grade he was given. The next semester he spent in Leipzig studying chemistry, which means that he probably registered at Erlangen only to obtain his medical doctorate.

As we learn from an investigation conducted at Tübingen, ${ }^{4}$ many medical students at that time registered between 17 and 18 years of age and studied for 3 to 4 years. The mean age at the time of their doctorate was 22 to 24 years and only a small percentage of all medical students underwent this costly procedure. Most of the inaugural dissertations that contained between 16 and 60 pages were not authored by the applicant himself. In this case, however, there is no doubt that Hahnemann was the author. ${ }^{6}$

His thoughts are fully absorbed by prescientific thinking never surpassing contemporary beliefs. Some of his quotations-as with tobacco-are even contradictory. Checking one page of his philological compilation for correctness from a contemporary point of view yields that about $62 \%$ of his entries concern conditions being able to cause spasms in the widest possible sense, while about $38 \%$ are not at all or-on the contrary-spasmolytic. From today's perspective the thesis contains virtually nothing of scientific value, being sometimes frankly incomprehensible. He restates and repeats in a loosely systematic way the philosophical and mystical thougths of an era that had little medical empirical data let alone scientific background. It was, for example, common belief at the end of the 18th century that the will commanded the nerves by setting into vibration an etheric substance enclosed in hollow canals within the nervous system. But it was known, as it is stated in the preface of the dissertation, that the muscles are dominated by nerves. The ability of a denervated muscle to contract was attributed to the remaining nervous fluid or vital spirit.

However, two remarkable mentions are made: one is that "severed nerves of the maxilla" may cause spasms being reminiscent in retrospect of trigeminal neuralgia and that the same may hold true for "nerves contracted by arteries", which may insinuate the notion of artery walls irritating the nerve's myelin sheath-a rather modern concept.

While it is indeed an example of the state of academic medical training, thinking, and writing of its time, the views and conclusions expressed in Hahnemann's thesis are of interest only to the historian. It is notable for being devoid of even the slightest attempt at proof and cannot claim to have any scientific value. It testifies that the development that led him to part from contemporary medicine must have started later in life. Nothing presages the iconoclast who created a "mundus inversus" yielding issues for debate over centuries.

He himself must have noticed his inability to have a glimpse beyond the status quo because he introduces ("in magnis et voluisse sat est") and concludes his "dissertatiuncula" with very humble remarks alluding to future scholars who should know better. In his own words it reads like this:

"I will frankly admit that the short time I had in preparing this dissertation was only suitable to draw a sketch. It is only to be hoped that in the future a more erudite and experienced person uses this unorderly and raw material for a more systematic and complete approach. If I will ever occasion to have the opportunity to augment and elaborate this laconic and aphoristic sketch I shall do so."

But he never did.

\section{J G Lang}

Neurological Hospital, Outpatient Department, University of ErlangenNuremberg at Erlangen, Schwabachanlage 6, 91054 Erlangen, Germany; christoph.lang@neuro.imed.uni-erlangen.de

\section{References}

1 Wittern R. Samuel Hahnemann (1755-1843). In: Engelhardt D von, Hartmann F, eds. Klassiker der Medizin. 2nd vol. Munich: Beck, 1991:37-50.

2 Gawlik W. Samuel Hahnemann. Synchronopse seines Lebens. Tübingen: Sonntag, 1996.

3 Schmidt JM, Kaiser D, eds. Gesammelte kleine Schriften von Samuel Hahnemann. Heidelberg: Haug, 2001.

4 Beese M. Die medizinischen Promotionen in Tübingen 1750-1799. Tübingen: Dissertation, 1977.

5 Kaiser W. Vor 200 Jahren: Medizinische Sonderpromotion des 18 Jahrhunderts am Halleschen Beispiel. Z Gesamte Inn Med 1991;46:288-95.

6 Schmidt JM. Die Publikationen Samuel Hahnemanns. Sudhoffs Arch 1988;72:14-36. 